\title{
Trace element geochemistry of Amba Dongar carbonatite complex, India: Evidence for fractional crystallization and silicate-carbonate melt immiscibility
}

\author{
JyotiRAnJAn S RAY* and P N Shukla \\ Physical Research Laboratory, Navrangpura, Ahmedabad 380 009, India. \\ *e-mail: jsray@prl.ernet.in
}

\begin{abstract}
Carbonatites are believed to have crystallized either from mantle-derived primary carbonate magmas or from secondary melts derived from carbonated silicate magmas through liquid immiscibility or from residual melts of fractional crystallization of silicate magmas. Although the observed coexistence of carbonatites and alkaline silicate rocks in most complexes, their coeval emplacement in many, and overlapping initial ${ }^{87} \mathrm{Sr} /{ }^{86} \mathrm{Sr}$ and ${ }^{143} \mathrm{Nd} /{ }^{144} \mathrm{Nd}$ ratios are supportive of their cogenesis; there have been few efforts to devise a quantitative method to identify the magmatic processes. In the present study we have made an attempt to accomplish this by modeling the trace element contents of carbonatites and coeval alkaline silicate rocks of Amba Dongar complex, India. Trace element data suggest that the carbonatites and alkaline silicate rocks of this complex are products of fractional crystallization of two separate parental melts. Using the available silicate melt-carbonate melt partition coefficients for various trace elements, and the observed data from carbonatites, we have tried to simulate trace element distribution pattern for the parental silicate melt. The results of the modeling not only support the hypothesis of silicate-carbonate melt immiscibility for the evolution of Amba Dongar but also establish a procedure to test the above hypothesis in such complexes.
\end{abstract}

\section{Introduction}

Carbonatites have long been recognized as magmatic rocks (e.g., Bell 1989). Very low silica and high incompatible trace element contents make them unique amongst igneous rocks. In spite of the fact that they represent a very small fraction of all the magmatic rocks, they have attracted considerable attention because of their unusual physicochemical properties. The study of carbonatites has substantially improved our understanding of many important mantle processes such as mantle metasomatism, melt extraction, recycling of crustal material into the mantle and mantle degassing. Also because of their large age distribution (from Archean to present) they provide us probably the best samples to study the secular evolution of the Earth's mantle (Bell and Tilton 2002). Even after a considerable amount of research some of the fundamental aspects of the origin and evolution of carbonatites still remain elusive. There is debate about the nature of the primary carbonatite melts, their mantle sources and the magmatic processes that precede their final emplacement into the crust. It is still not clear whether the carbonate melts represent direct silica-undersaturated magmas from mantle (e.g., Harmer and Gittins 1998) or are products of magmatic differentiation, the latter being either fractional crystallization (e.g., Petibon et al 1998) carbonate-silicate melt immiscibility of carbonated silicate melts (e.g., LeBas 1989). Experimental findings appear to support all three possible scenarios (e.g., Sweeney 1994; Lee and Wyllie 1997; Veksler et al 1998a). However,

Keywords. Carbonatite; Amba Dongar; India; liquid immiscibility; trace elements; REE. 
the observed coexistence of carbonatites and alkaline silicate rocks in most complexes; experimental results suggesting existence of silicate-carbonate liquid immiscibility at crustal and mantle depths; their overlapping initial ${ }^{87} \mathrm{Sr} /{ }^{86} \mathrm{Sr}$ and ${ }^{143} \mathrm{Nd} /{ }^{144} \mathrm{Nd}$ ratios; and above all the absence of expected high $\mathrm{Mg}$ number primary melts suggest that in most cases carbonate-silicate liquid immiscibility played a major role. Therefore, there is a need for a robust method to test such a possibility using a variety of geochemical tracers.

Trace elements including the rare earth elements (REE) have been used extensively as successful tracers of magmatic processes. Carbonatites are known to have unusually high concentrations of incompatible trace elements (e.g., Woolley and Kempe 1989). It has also been observed that many of the traditionally incompatible elements often become compatible in carbonatite system (e.g., Dunworth and Bell 2001). These aspects make the study of trace elements in carbonatites intriguing. Although many earlier studies have utilized trace element variations in carbonatites to understand the complexities of their evolution (e.g., Keller and Spettel 1995), only a few have applied any quantitative method to identify the major processes, such as liquid immiscibility, involved in their genesis. This could have been largely due to the lack of comprehensive knowledge about the partitioning behaviour of trace elements during carbonatite evolution. There have been attempts to understand partitioning of elements from their natural distribution in various minerals of carbonatites (e.g., Dawson et al 1994; Ionov and Harmer 2002; Dawson and Hinton 2003), but similar work on coexisting alkaline silicate rocks is lacking. Experimental studies to determine mineral-melt $K_{d}$ values for carbonatite constituents are meager (e.g., Klemme and Dalpé 2003; Klemme and Meyer 2003) but a few studies exist that examine the partitioning of trace elements in a two-liquid (carbonatesilicate) system (Wendlandt and Harrison 1979; Hamilton et al 1989; Jones et al 1995; Veksler et al 1998b). The results of these studies can be used to test the liquid immiscibility hypothesis in a given carbonatite-alkaline complex. In this work we make such an effort to understand the origin and evolution of carbonatites and associated alkaline silicate rocks of Amba Dongar complex, western India using trace element data and the existing knowledge of their partitioning behavior.

\section{Geology of Amba Dongar complex}

The Amba Dongar carbonatite complex is located $2 \mathrm{~km}$ north of the Narmada river in the state of Gujarat, western India and forms a part of a large alkaline subprovince (Chhota Udaipur, figure 1) in the Deccan Flood Basalt Province. Carbonatites (calcite and ferro), carbonatite breccias, alkaline silicate rocks and hydrothermal fluorite deposit make up most of the complex. The complex itself intrudes Precambrian basement gneisses, Cretaceous Bagh sediments (sandstone and limestone) and older flows of Deccan tholeiites. The age of the complex (65 Ma; Ray and Pande 1999) suggests its late emplacement during the Deccan volcanism. The identical emplacement ages of alkaline silicate rocks and carbonatites of this complex hint at a genetic relationship between them (Ray et al 2000a).

The geology of this complex and nearby area has been studied in great detail since its discovery four decades ago (e.g., Gwalani et al 1993; Viladkar 1996; Srivastava 1997; Ray et al 2000a and references therein). A brief account of the important features of the complex is given here. Amba Dongar is one of the best examples of carbonatite ring dike complex (possibly a diatreme). Concentric ring dikes of calcite carbonatite and carbonatite breccias intrude $\sim 68$ Ma old tholeiitic flows (Ray et al 2003), which also occupy the central depression (figure 1). Ferrocarbonatite occurs as plugs in the southern part of the ring dike and as small dikes/veins in the main ring. The alkaline silicate rocks, primarily nephelinites, nepheline syenites and phonolites, occur as plugs and dikes in the low surrounding areas of the main carbonatite dome at Amba Dongar and adjoining area (figure 1). Geochronology of various magmatic activities in the Chhota Udaipur subprovince indicates that all the alkaline and alkaline-carbonatite complexes of the region $\left(\sim 1200 \mathrm{~km}^{2}\right.$, figure 1$)$ are coeval (Basu et al 1993; Iwata 1997; Ray and Pande 1999; Ray et al 2003). Earlier geochemical and isotopic (radiogenic and stable) studies in Amba Dongar have revealed that:

- the carbonatites are magmatic and bear signatures of an enriched mantle source (Simonetti et al 1995; Ray and Ramesh 1999),

- ${ }^{87} \mathrm{Sr} /{ }^{86} \mathrm{Sr}$ ratios of carbonatites and silicate rocks point towards their cogenesis and suggest that the primary magma for the complex had assimilated a small amount of lower crustal material (Ray 1998; Ray et al 2000b),

- the ferrocarbonatites represent the final phase of igneous activity (Viladkar and Dulski 1986), and

- the variations of major and trace elements in carbonatites have been attributed to closed-system fractional crystallization (Viladkar and Wimmenauer 1992).

Geochemical and isotopic studies on alkaline silicate rocks of the complex and subprovince are limited (Ray 1998; Viladkar 1996 and references 

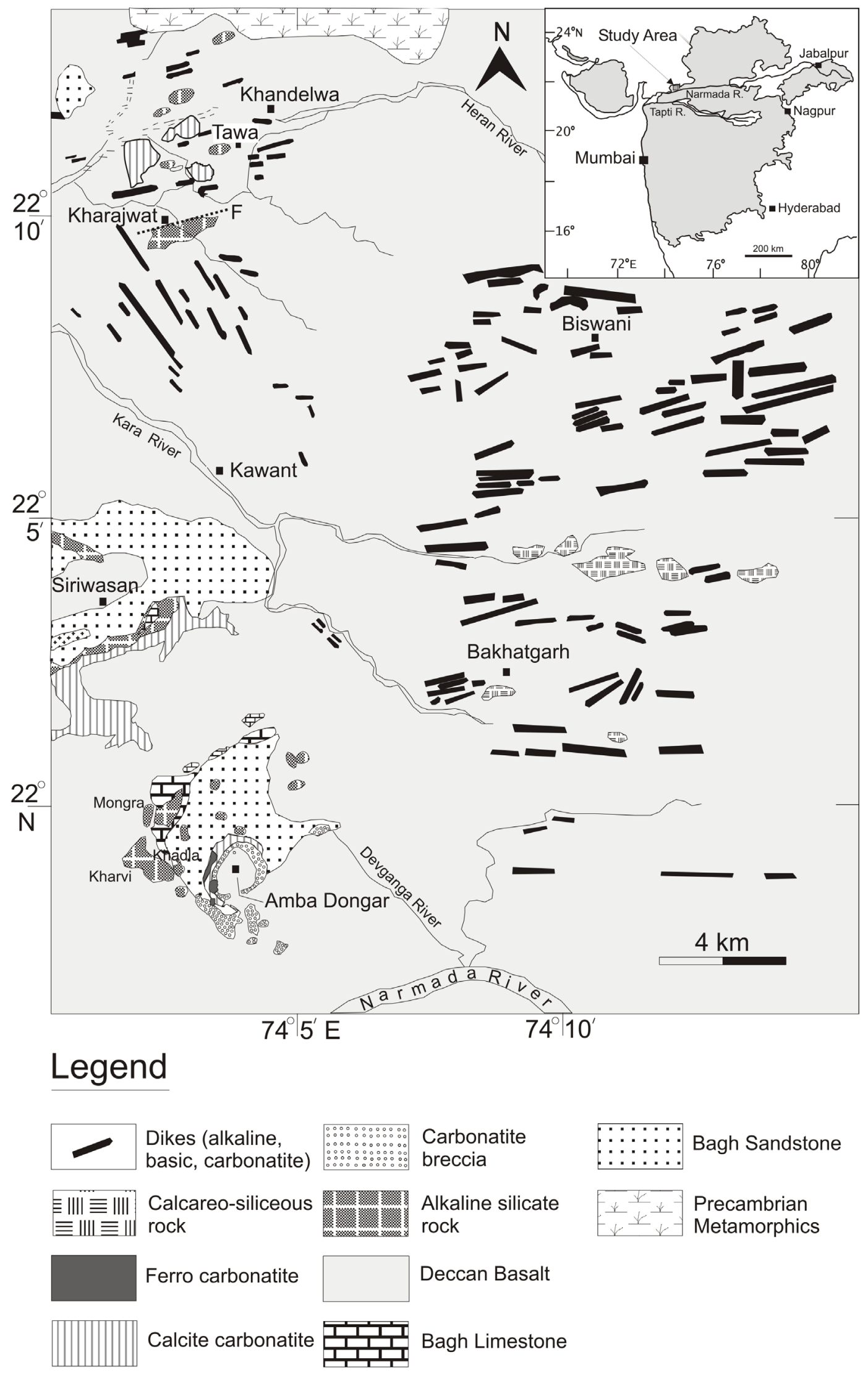

Figure 1. A generalized geological map of a portion of the Chhota Udaipur alkaline-carbonatite sub-province of the Deccan Flood Basalt Province, western India (inset) showing the exposed lithologies. The Amba Dongar ring dike complex is located at the southwest corner of the map. The map has been modified from Gwalani et al (1993). 
therein) and there has been no serious attempt to establish the genetic relationship (if any) between these and the carbonatites. Here we make an effort to achieve this by modeling the trace element data - existing and newly generated by us - from the complex.

\section{Methodology}

Trace element concentrations in carbonatites and alkaline silicate rocks from Amba Dongar complex were analyzed by instrumental neutron-activation analysis (INAA). The samples were crushed, dried at $110^{\circ} \mathrm{C}$ and packed (100 mg aliquots) in small aluminum foils and sealed in a quartz vial. The quartz vial was then put in a container suitable for irradiation at the CIRUS reactor of the Bhabha Atomic Research Center, Mumbai, India. The neutron flux in this reactor is $\sim 10^{13} \mathrm{n} \mathrm{cm}^{-2} \mathrm{~s}^{-2}$. The samples were irradiated for 15 days together with BCR1 (USGS basalt standard). After irradiation, the gamma-ray spectra of the samples were obtained using a coaxial Germanium detector $\left(148-\mathrm{cm}^{3}\right.$, high purity Ge-detector having a resolution of $2.2 \mathrm{keV}$ for $1333 \mathrm{keV}$ gamma rays of ${ }^{60} \mathrm{Co}$ ). Counting of samples and the standard was done and concentration of trace elements (including nine rare earth elements) was measured following the standard procedures outlined by Laul (1979). The reproducibility $( \pm 1 \sigma)$ of concentration was better than $\pm 1 \%$ for $\mathrm{La}, \mathrm{Ce}, \mathrm{Sm}, \mathrm{Eu}$, and $\mathrm{Tb} ; \pm 2.5 \%$ for $\mathrm{Nd}$, $\mathrm{Sr}, \mathrm{Yb}, \mathrm{Lu}$, and $\mathrm{Ba} ; \pm 5 \%$ for $\mathrm{Gd} ; \pm 10 \%$ for $\mathrm{Zr}$; and $\pm 20 \%$ for Hf.

\section{Results and discussion}

\subsection{Trace element variations}

Concentrations of $\mathrm{Ba}, \mathrm{Sr}, \mathrm{Zr}, \mathrm{Hf}$ and nine $\mathrm{REE}$ were measured in four calcite carbonatites, three ferrocarbonatites and three alkaline rocks (nephelinite and phonolitic nephelinite). The data are presented in table 1. Primitive mantle-normalized trace element patterns and chondrite-normalized REE patterns of the analyzed samples are presented in figure 2 . The concentrations and patterns observed in Amba Dongar resemble those observed in most of the carbonatite complexes worldwide (e.g., Woolley and Kempe 1989). The data for average calcite carbonatites and ferrocarbonatites (Woolley and Kempe 1989) lie well within the ranges observed in Amba Dongar (figure 2). The following observations can be made from our data in figure 2:

- large ion lithophile elements (LILE), except for $\mathrm{Rb}$, show a general trend of increasing concentration in the order silicate rocks-calcite carbonatites-ferrocarbonatites,

- all rock types of the complex depict LREE enriched chondrite-normalized REE patterns,

- $\mathrm{Rb}$ and Hf contents are higher in silicate rocks and the latter shows a large negative anomaly in carbonatites, whereas patterns for Zr and HREE for all rock types overlap, and

- the apparent negative anomaly shown by $\mathrm{Sr}$ is a result of higher abundance of $\mathrm{Ce}$ and $\mathrm{Nd}$ compared to Sr and not a result of any magmatic/secondary process.

Although there exists isotopic evidence for minor crustal contamination in Amba Dongar (Ray 1998) the fact that the concentration of most of the trace elements considered here is much higher than that in crustal rocks, rules out any significant distortion of primary signatures.

\subsection{Fractional crystallization in Amba Dongar}

The increase in LREE and Ba contents from calcite carbonatite through ferrocarbonatites to Ba-rich ferrocarbonatites in Amba Dongar, like many carbonatite complexes worldwide (e.g., LeBas 1989), is indicative of fractional crystallization of parental carbonate melt for Amba Dongar. The effect of FC is more pronounced in the chondrite-normalized $\mathrm{La} / \mathrm{Yb}$ vs. La plot (figure 3), where it can be clearly seen that La being highly incompatible, has partitioned more into the late crystallized ferrocarbonatites. A fractionation trend is also observed for the silicate rocks. Generation of carbonatites as a result of fractional crystallization of carbonated silicate magma is a known possibility (e.g., Korobeinikov et al 1998; Veksler et al 1998a). This would mean that crystallization trends in alkaline rocks and carbonatites should have identical slopes. However, the trends observed for Amba Dongar data in $(\mathrm{La} / \mathrm{Yb})_{\mathrm{CN}}$ versus $(\mathrm{La})_{\mathrm{CN}}$ plot (figure $3 \mathrm{~A}$ ) rule out such a possibility. The confirmation that silicate rocks and carbonatites of Amba Dongar evolved independently comes from the plot of chondrite-normalized $\mathrm{Nd} / \mathrm{Sr}$ versus $\mathrm{Sr}$ (figure 3B). Nd is incompatible in both silicate and carbonate systems, but more so in latter and therefore, the slope of the fractional crystallization trend in carbonatites is higher (figure $3 \mathrm{~B}$ ).

The overlapping distribution of $(\mathrm{La} / \mathrm{Yb})_{\mathrm{CN}}$ versus $(\mathrm{La})_{\mathrm{CN}}$ in calcite carbonatites and ferrocarbonatites (figure 3A) can also be considered as an evidence for their derivation from one single melt by fractional crystallization. Further support for fractional crystallization in calcite carbonatites, the major carbonatite type in Amba Dongar, comes from the stable $\mathrm{C}$ and $\mathrm{O}$ isotopes 
Table 1. Samples collected from Amba Dongar and adjoining region for this study.

\begin{tabular}{|c|c|c|c|}
\hline Sample no. & Location & Rock type & Major mineralogy \\
\hline $\mathrm{AD}-10$ & Main fluorite mine & Calcite carbonatite & $\begin{array}{l}\text { Monomineralic, coarse grained } \\
\text { calcite }\end{array}$ \\
\hline $\mathrm{AD}-31$ & Western limb of the ring dike & Calcite carbonatite & $\begin{array}{l}\text { Coarse grained calcite, apatite, } \\
\text { phlogopite }\end{array}$ \\
\hline $\mathrm{AD}-38$ & Western limb of the ring dike & Calcite carbonatite & $\begin{array}{l}\text { Coarse grained calcite, apatite, } \\
\text { magnetite, fluorite }\end{array}$ \\
\hline $\mathrm{AD}-43$ & Eastern limb of the ring dike & Calcite carbonatite & $\begin{array}{l}\text { Fine grained calcite, magnetite, } \\
\text { apatite }\end{array}$ \\
\hline AD-12 & $\begin{array}{l}\text { Southernmost ankeritic car- } \\
\text { bonatite plug }\end{array}$ & Ferro carbonatite & $\begin{array}{l}\text { Fine grained ankerite/dolomite, } \\
\text { calcite, magnetite }\end{array}$ \\
\hline AD-19 & $\begin{array}{l}\text { Ankeritic vein from the } \\
\text { western limb }\end{array}$ & Ferro carbonatite & $\begin{array}{l}\text { Fine grained calcite, ankerite/ } \\
\text { dolomite, magnetite, apatite }\end{array}$ \\
\hline $\mathrm{AD}-36$ & $\begin{array}{l}\text { Southern-eastern ankeritic } \\
\text { carbonatite plug }\end{array}$ & Ferro carbonatite & $\begin{array}{l}\text { Fine grained ankerite/dolomite, } \\
\text { calcite, magnetite }\end{array}$ \\
\hline $\mathrm{AD}-17$ & Khadla Village & Nephelinite & $\begin{array}{l}\text { Nepheline, aegirine augite, } \\
\text { melanite, apatite }\end{array}$ \\
\hline $\mathrm{AD}-45$ & $\begin{array}{l}\text { A plug north of main ring } \\
\text { dike }\end{array}$ & Phonolitic nephelinite & $\begin{array}{l}\text { Nepheline, aegirine augite, ortho- } \\
\text { clase, calcite }\end{array}$ \\
\hline $\mathrm{AD}-47$ & $\begin{array}{l}\text { A plug northwest of main } \\
\text { ring dike (near Mongra) }\end{array}$ & Phonolitic nephelinite & $\begin{array}{l}\text { Nepheline, aegirine augite, ortho- } \\
\text { clase, calcite }\end{array}$ \\
\hline
\end{tabular}

Table 2. Trace element concentration (in ppm) measured in carbonatites and alkaline silicate rocks of Amba Dongar.

\begin{tabular}{|c|c|c|c|c|c|c|c|c|c|c|}
\hline & $\mathrm{AD}-10^{\mathrm{C}}$ & $\mathrm{AD}-31^{\mathrm{C}}$ & $\mathrm{AD}-38^{\mathrm{C}}$ & $\mathrm{AD}-43^{\mathrm{C}}$ & $\mathrm{AD}-12^{\mathrm{FC}}$ & $\mathrm{AD}-19^{\mathrm{FC}}$ & $\mathrm{AD}-36^{\mathrm{FC}}$ & $\mathrm{AD}-17^{\mathrm{A}}$ & $\mathrm{AD}-45^{\mathrm{A}}$ & $\mathrm{AD}-47^{\mathrm{A}}$ \\
\hline $\mathrm{Rb}^{*}$ & 12 & 10 & 14 & 10 & 18 & 19 & 21 & 48.9 & 88.5 & 90.9 \\
\hline $\mathrm{Ba}$ & 1736 & 8779 & 2663 & 8974 & 114630 & 8553 & 28684 & 552 & 1623 & 573 \\
\hline $\mathrm{La}$ & 325 & 1372 & 356 & 971 & 3464 & 2084 & 5620 & 161 & 139 & 34 \\
\hline $\mathrm{Ce}$ & 581 & 2465 & 615 & 1794 & 5528 & 4276 & 6241 & 227 & 264 & 61 \\
\hline $\mathrm{Sr}$ & 4557 & 5942 & 2777 & 1343 & 3065 & 1670 & 3378 & 2457 & 1406 & 123 \\
\hline $\mathrm{Nd}$ & 209 & 938 & 215 & 640 & 778 & 1583 & 935 & 69 & 120 & 25 \\
\hline $\mathrm{Zr}$ & 258 & 905 & 216 & 446 & 448 & 1165 & 472 & 741 & 683 & 197 \\
\hline $\mathrm{Hf}$ & 0.25 & 0.77 & 0.34 & 0.62 & 0.47 & 0.64 & 0.32 & 10.2 & 9.4 & 3 \\
\hline $\mathrm{Sm}$ & 26.4 & 137.5 & 16.4 & 63 & 82.2 & 180 & 95.1 & 10.4 & 18.4 & 4.6 \\
\hline $\mathrm{Eu}$ & 7 & 29.5 & 7 & 17.1 & 17 & 42.3 & 19.9 & 2.8 & 5 & 1.1 \\
\hline Gd & 14.6 & 110.5 & 17.5 & 51.8 & 61.7 & 96.1 & 72.7 & 9.5 & 13.4 & 4 \\
\hline $\mathrm{Tb}$ & 1.6 & 7.9 & 2.1 & 4.1 & 3.6 & 10.2 & 5 & 1.2 & 1.9 & 0.6 \\
\hline $\mathrm{Yb}$ & 3.1 & 23.2 & 4.3 & 6.9 & 13.1 & 10.2 & 20.5 & 3.5 & 4.8 & 2.5 \\
\hline $\mathrm{Lu}$ & 0.44 & 1.64 & 0.55 & 0.54 & 0.84 & 0.96 & 1.2 & 0.51 & 0.65 & 0.4 \\
\hline
\end{tabular}

$\mathrm{C}=$ calcite carbonatite; $\mathrm{FC}=$ ferrocarbonatite; $\mathrm{A}=$ alkaline silicate rock.

${ }^{*} \mathrm{Rb}$ measurements are by IDTIMS (Ray et al 2000b). 

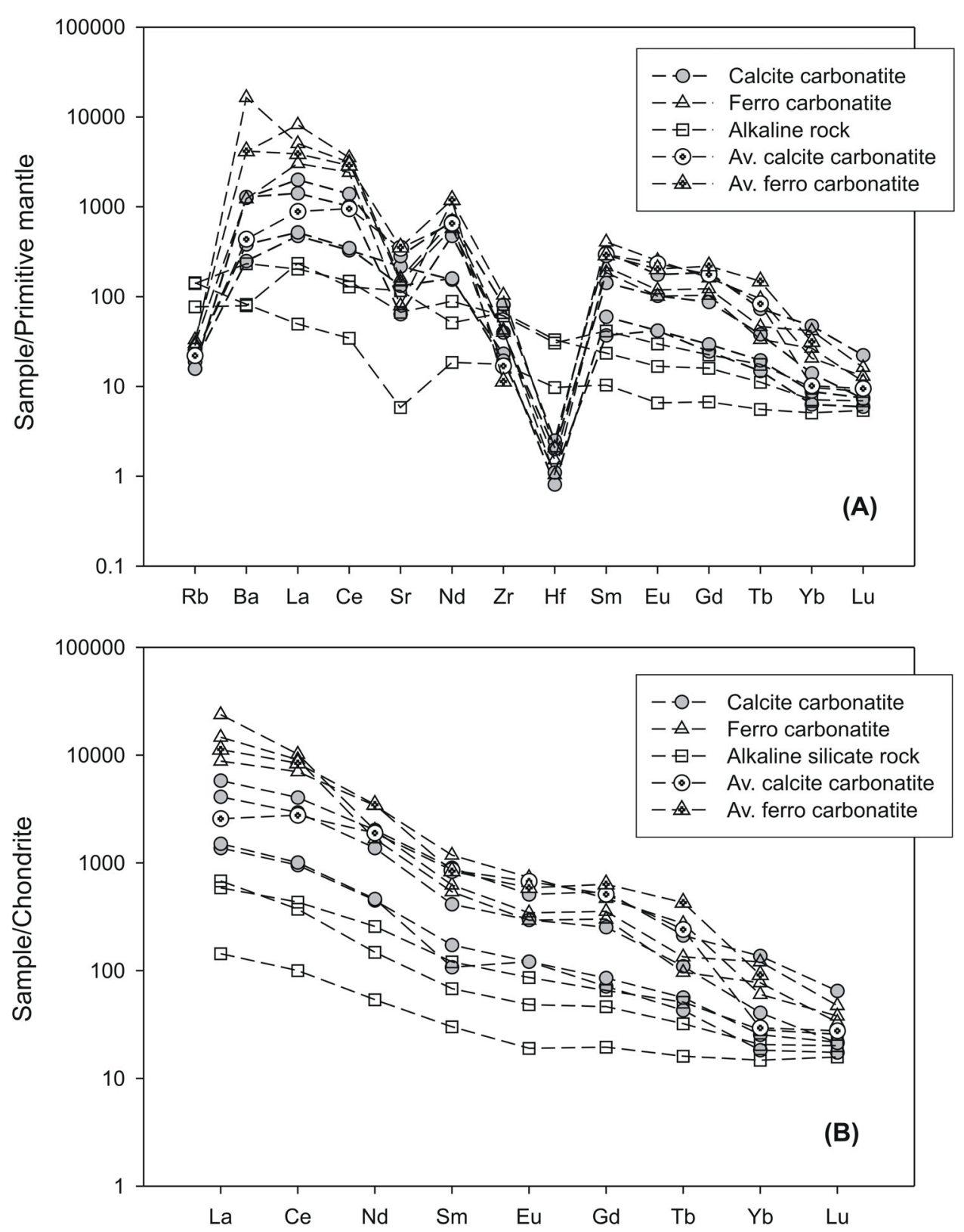

Figure 2. (A) Primitive mantle-normalized trace element spidergrams for various rock types of Amba Dongar complex (analyzed by us). The elements are plotted from left to right in order of increasing compatibility in a basaltic system. Normalization factors are from Sun and McDonough (1989). Data for average calcite carbonatite and ferrocarbonatite are from Woolley and Kempe (1989). (B) Chondrite-normalized rare earth element spidergrams for same samples as in (A).

(Ray and Ramesh 1999). Combined trace element and isotopic variations also support this inference. In a plot of $(\mathrm{La} / \mathrm{Yb})_{\mathrm{CN}}$ versus $\delta^{18} \mathrm{O}$, calcite carbonatites show a good positive correlation (figure $4 \mathrm{~A})$. However, because of the altered nature of $\delta^{18} \mathrm{O}$, the same cannot be assessed for the ferrocarbonatites. To determine whether the calcite carbonatites and ferrocarbonatites of Amba Dongar belong to a single crystallization sequence and do not represent two separate parental magmas we took the help of $(\mathrm{Ba} / \mathrm{Sr})_{\mathrm{CN}}$ versus $(\mathrm{Ba})_{\mathrm{CN}}$ plot (figure $4 \mathrm{~B})$. Ba is believed to be highly incompatible during the crystallization of carbonatite minerals (e.g., Ionov and Harmer 2002; Klemme and Dalpé 2003), whereas Sr abundance appears to remain constant (Ionov and Harmer 2002). Therefore, in the above plot one would expect that the data from both types of carbonatites plot in a straight 

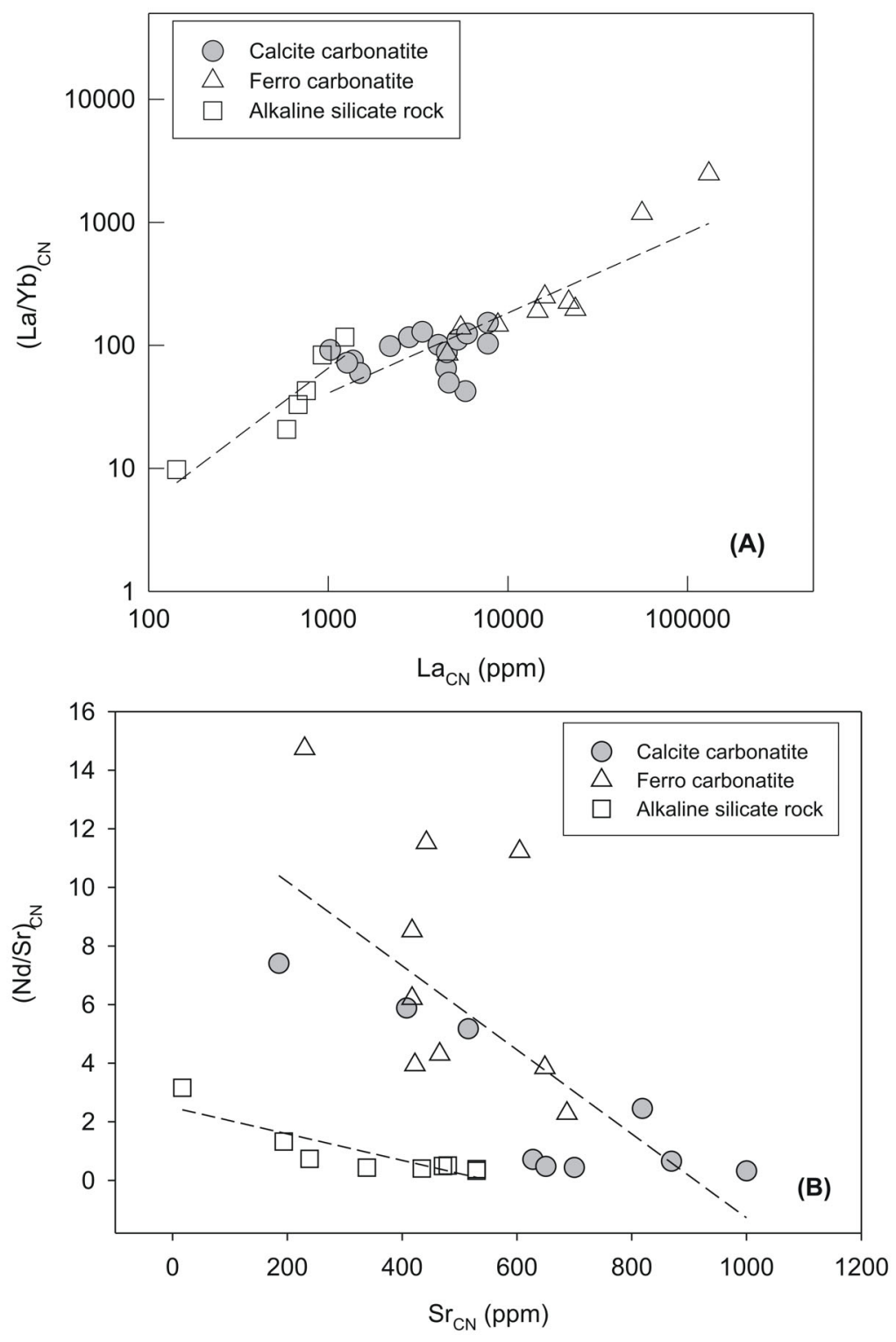

Figure 3. (A) Plot of chondrite-normalized La/Yb ratios versus La concentrations of alkaline silicate rocks and coexisting carbonatites of Amba Dongar. Dashed lines are linear regressions on silicate rocks and carbonatites (both types combined). (B) Plot of chondrite-normalized Nd/Sr ratios versus Sr concentrations of same samples as in figure (A). Dashed lines are linear regressions showing the trends of fractional crystallization.

line that passes through the origin with a slope of $1 / \mathrm{Sr}$ (i.e., $\sim 0.00227 \pm 0.00126$ for our data). A linear regression on all the data points in figure 4(B) yields a good correlation between both the variables $\left(r^{2}=0.9\right)$ and the intercept and slope of the straight line are 0.09 and 0.00253 , respectively. These values are within acceptable limits of the expected values and therefore, confirm our view that the calcite carbonatites and ferrocarbonatites of the complex have fractionally crystallized from a single parental melt.

From the above discussion it is apparent that two independent crystal fractionation processes, involving two separate parental melts (a silicate melt and a carbonate melt), were responsible for the formation of the alkaline silicate rocks and carbonatites of Amba Dongar. However, it is not clear from the data whether there existed any genetic relationship between these two parental melts. As mentioned above, identical emplacement ages (Ray and Pande 1999) and overlapping initial ${ }^{87} \mathrm{Sr} /{ }^{86} \mathrm{Sr}$ ratios (Ray 1998; Ray et al 2000a) of carbonatites and alkaline silicate rocks lend support to the cogenesis hypothesis and suggest that liquid immiscibility may have been the cause of their coexistence. At this juncture we would like to make this clear that in the paper a single mantle-derived magma has been referred as "primary", and any melt derived 

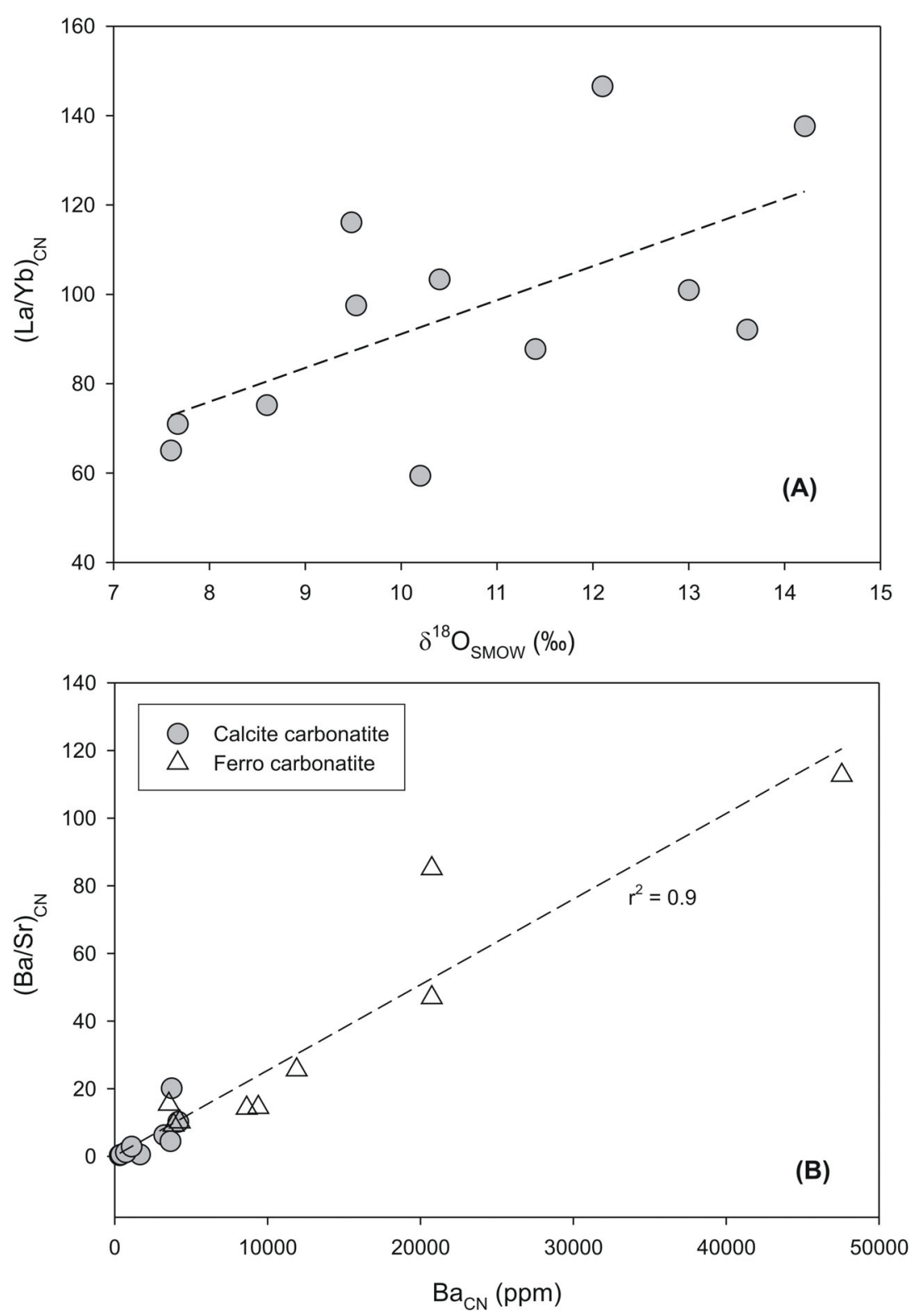

Figure 4. (A) Plot of chondrite-normalized $\mathrm{La} / \mathrm{Yb}$ ratios versus oxygen isotopic compositions of calcite carbonatites of Amba Dongar. The linear regression (dashed line) has an $r^{2}$ value of 0.4 at $95 \%$ confidence level. Oxygen isotope data are from Ray and Ramesh (1999) and Viladkar (1996). (B) Plot of chondrite-normalized Ba/Sr ratios versus Ba concentrations of Amba Dongar calcite carbonatites and ferrocarbonatites. The linear regression on the combined data has an $r^{2}$ value of 0.9 at $95 \%$ confidence level.

from this magma, as a result of magmatic differentiation, as "parental".

\subsection{A test for liquid immiscibility}

Trace elements are very powerful tracers of magmatic processes and would be likely to have recorded the immiscibility process during the magmatic evolution of the complex. To uncover the evidences for this process, we present a simple conservative model first assuming that the parental melts for Amba Dongar have been derived from a parent carbonated silicate magma by liq- uid immiscibility and then generate a trace element distribution pattern for the silicate melt using the observed trace element abundance in carbonatites and available carbonate melt-silicate melt partition coefficients (Hamilton et al 1989; Jones et al 1995; Veksler et al 1998b). If our assumptions were legitimate then the model-generated pattern for the silicate melt should lie within the observed concentration field for the alkaline silicate rocks.

In a fractional crystallization process (Rayleigh type), concentration of a particular element in the crystallizing solids $C_{s}$ evolves as: 


$$
C_{s}=C_{o} D f^{(D-1)},
$$

where $C_{o}$ is the original concentration in a parental melt, $D$ - the rock-melt distribution coefficient, and $f$ - the fraction of remaining melt. If the equation (1) is considered for a carbonate-melt then by determining $C_{o}$, we should be able to establish the initial concentration of the element in the silicate melt with the help of silicate meltcarbonate melt partition coefficient. Determination of $C_{o}$ is tricky because it is difficult to identify the first and last crystallized products of a magma in a given complex. In the case of Amba Dongar, there have been reports of monominerallic calcite carbonatite cumulates being present as xenoliths (e.g., Viladkar 1996). The incompatible trace element concentrations in these are much lower compared to that in an average calcite carbonatite of the complex (Viladkar and Dulski 1986; Viladkar 1996). Considering the fact that such elements are concentrated in the remaining liquid (not in the crystals) during the early stages of fractional crystallization we assume the above cumulates to represent the initial products of fractional crystallization of the parental carbonate melt. Similarly, we consider the extremely LREE and Ba enriched manganeferous ferrocarbonatites present as thin veins in the ferrocarbonatite plugs located south of the complex (Viladkar 1996) as the end products of fractional crystallization. For the model calculations we assume that the cumulate calcite carbonatite represents the product at $f=1$, whereas the manganeferous ferrocarbonatite the product at $f=0.01$ and 0.0001 , in two separate cases. Using equation (1) we get two simultaneous equations for concentration of an element in the carbonatite.

$$
\begin{aligned}
C_{s}^{i} & =C_{o} D \\
C_{s}^{f} & =C_{o} D(0.01)^{(D-1)}
\end{aligned}
$$

or

$$
C_{s}^{f}=C_{o} D(0.0001)^{(D-1)},
$$

where $C_{s}^{i}$ and $C_{s}^{f}$, respectively represent the initial and final concentrations. Solving for $D$ and $C_{o}$, we get

$$
D=1+\left[\ln \left(C_{s}^{f} / C_{s}^{i}\right)\right] /[\ln (0.01)]
$$

or

$$
D=1+\left[\ln \left(C_{s}^{f} / C_{s}^{i}\right)\right] /[\ln (0.0001)]
$$

and

$$
C_{o}=C_{s}^{i} / D
$$

Using equations (4) and (5), the $C_{o}$ values for several trace elements for which carbonate meltsilicate melt partition coefficients are available are calculated. Considering the fact that the measured concentrations $\left(C_{s}^{i}\right.$ and $\left.C_{s}^{f}\right)$ have analytical errors and the rocks considered for $f=1$ and $f=0.01$ or 0.0001 may not be the true representatives, a conservative $2 \sigma$ error of $20 \%$ has been assigned to the estimated $C_{o}$.

The concentrations of these elements in the silicate melt $\left(C_{s m}\right)$ are then determined using the following relation.

$$
C_{s m}=C_{o} K_{d},
$$

where $K_{d}$ is the silicate melt-carbonate melt partition coefficient for the elements under consideration. The experimental determination of silicate-carbonate $K_{d}$ values by Hamilton et al (1989) is by far the most exhaustive. For our calculations, we use the maximum and minimum values determined at pressures 1-6 kbar and temperatures $1050-1250^{\circ} \mathrm{C}$ for the nephelinite-Ca-carbonatite system (figure $5 \mathrm{~A}$ and $\mathrm{B}$ ), and at $0.8-6 \mathrm{kbar}$ in the same temperature range for the phonolite-Nacarbonatite system (figure 6B). Calculations are also performed using the $K_{d}$ values of Jones et al (1995) at $10 \mathrm{kbar}$ and Veksler et al (1998b) at 0.8$0.9 \mathrm{kbar}$ (figure $6 \mathrm{~A}$ ). Although the $K_{d}$ values at all the pressure ranges are considered for calculations, from the available geologic information (e.g., study of fenites and fluid inclusions) we believe that the primary magma for Amba Dongar probably experienced an overhead pressure exceeding 3 kbar (Viladkar 1996; William-Jones and Palmer 2002) during possible immiscible separation in a magma chamber. Using equation (6) we calculate the theoretical $C_{\mathrm{sm}}$ values for Amba Dongar. The error in $C_{\mathrm{sm}}$ (two standard deviation) is calculated using the standard error propagation theory (Bevington et al 2002). The primitive mantle normalized concentrations of the elements in the silicate melts (expected maximum and minimum values) are plotted in figures 5 and 6 along with the observed concentration fields for carbonatite and alkaline silicate rocks of Amba Dongar for comparison. Model curves in figure 5(A) and 5(B) present results of calculations when the manganeferous ferrocarbonatites veins are derived from the carbonate melt at $f=0.01$ and $f=0.0001$, respectively. Model curves in figures 6(A) and 6(B) both present results of calculations for $f=0.0001$.

If the alkaline silicate rocks were crystallized fractionally from a parental silicate melt then one would expect the pattern for this melt to fall within the observed field for the silicate rocks. At this juncture we would like to point out that the existing data of trace elements for alkaline silicate rocks 

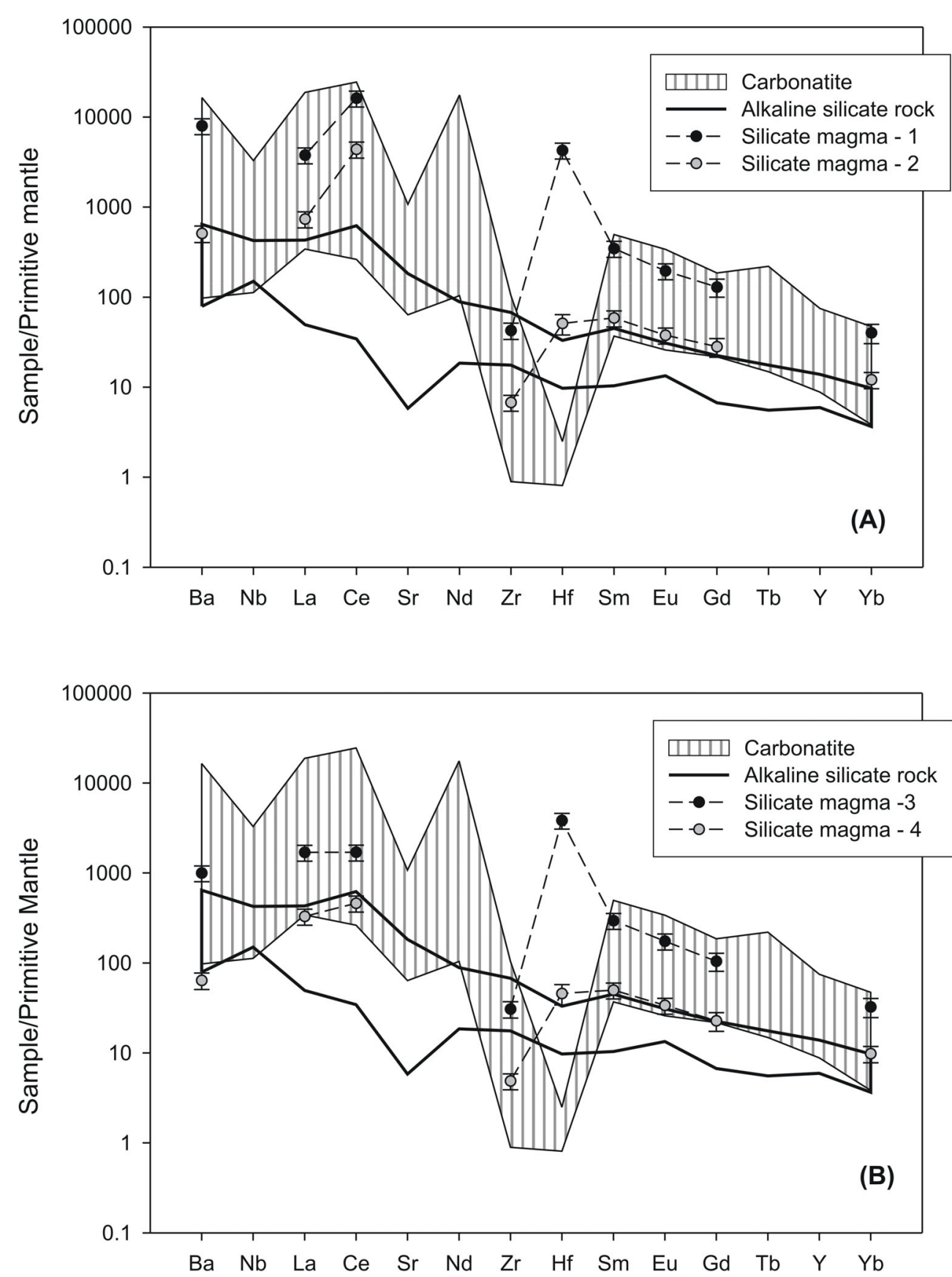

Figure 5. Primitive mantle-normalized trace element concentration ranges for selected trace elements of carbonatites and alkaline silicate rocks of Amba Dongar and model generated expected concentrations in primary silicate magma. The figures also include data from Gwalani et al (1993), Srivastava (1997), Viladkar (1996), Viladkar and Dulski (1986), and Viladkar and Wimmenauer (1992). (A) Silicate magma -1 and 2, respectively represent model estimates based on maximum and minimum values of $K_{d}$ (silicate melt-carbonate melt) in the nephelinite-Ca-carbonatite system of Hamilton et al (1989). The calculations are based on the assumption that the maximum and minimum observed concentrations in carbonatites represent crystallization products at $f$ (fraction of remaining melt) $=1$ and 0.01 , respectively. (B) Silicate magma -3 and 4 are for the same values as in (A) but in this case the calculations are done assuming the maximum and minimum observed concentrations in carbonatites representing crystallization products at $f=1$ and 0.0001 , respectively.

of Amba Dongar is limited, therefore the field shown in figures 5 and 6 for silicate rocks may actually represent a portion of the entire range. Our modeling results reveal that in a nephelinite-Cacarbonatite system, the expected concentrations of six out of nine trace elements overlap or fall in the observed field when $f=0.01$ and $K_{d}$ values are minimum (figure 5A). This observation extends to eight trace elements for the same $K_{d}$ values when $f=0.0001$ (figure 5B). Clearly the model concentrations of all the elements considered except $\mathrm{Zr}$ support two-melt-immiscibility hypothesis at 

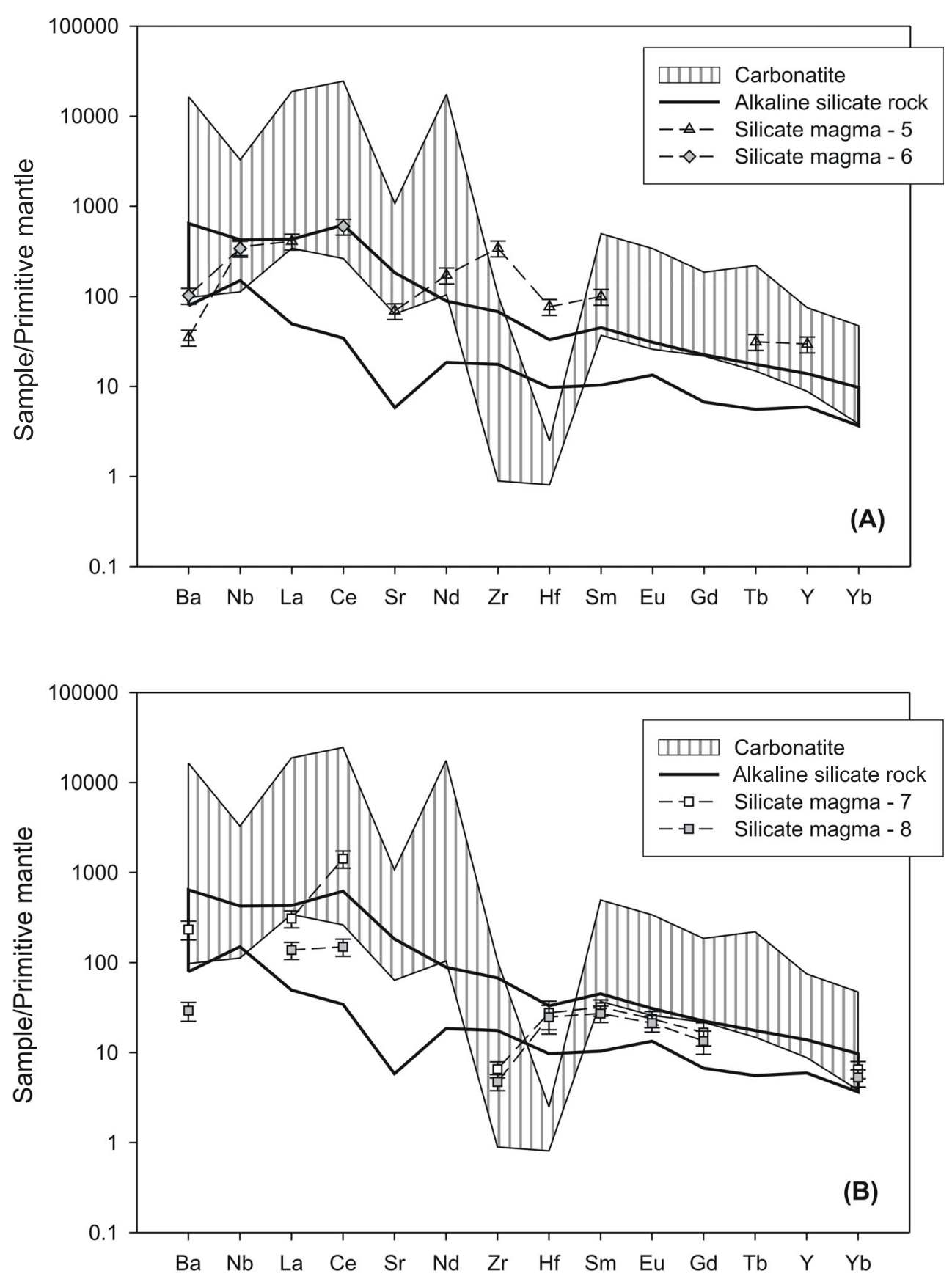

Figure 6. Primitive mantle-normalized trace element concentration ranges for selected trace elements of carbonatites and alkaline silicate rocks of Amba Dongar and model generated expected concentrations in primary silicate magma. Data as in figure 5. (A) Silicate magma -5 and 6 , respectively represent model estimates based on $K_{d}$ (silicate melt-carbonate melt) values from Veksler et al (1998b) and Jones et al (1995). Calculations are done assuming the maximum and minimum observed concentrations in carbonatites to be $f=1$ and 0.0001 , for both scenarios. (B) Silicate magma -7 and 8 , respectively are for maximum and minimum $K_{d}$ values in the phonolite-Na-carbonatite system of Hamilton et al (1989). Other parameters are the same as in figure $5(\mathrm{~B})$.

higher pressures (3-6 kbar) for Amba Dongar. The manganeferous ferrocarbonatite veins, being the terminal phase activity, are likely to represent the residual melt with $f$ value lower than 0.0001 (or $0.01 \%$ ), which is realistic. Further support for the hypothesis of carbonate-silicate melt-immiscibility at high pressure comes from the model-estimated concentrations of $\mathrm{Ba}, \mathrm{Nb}$ and $\mathrm{Ce}$ using the $K_{d}$ values (at $10 \mathrm{kbar}$ ) of Jones et al (1995) (figure 6A). Figure 6(A) also shows that the model values based on Veksler et al (1998b)'s low pressure $K_{d}$ data (for $0.8-0.99 \mathrm{kbar})$ fail to support the same.

Clearly, the results of the modeling calculations support the view that the rocks of Amba Dongar 
owe their existence to an immiscible separation of a nephelinitic silicate melt and a Ca-carbonate melt from a primary carbonated-silicate melt that happened early in the evolutionary history. However, considering the ubiquity of phonolites in the Chhota Udaipur sub-province (e.g., Viladkar 1996) it would be worthwhile to examine the possibility of phonolite-Ca-carbonatite melt immiscibility. Unfortunately experimental $K_{d}$ values for such a system are not available. Therefore, we use the values of Hamilton et al (1989) for a phonoliteNa-carbonatite system for our model calculations (figure 6B). Surprisingly, the expected concentrations of all the elements (barring Zr) show an excellent overlap with the observed field for the silicate rocks of Amba Dongar (figure 6B) and the pattern appears to be independent of temperature and pressure. Although the above system - because it involves Na-carbonatites - is not suitable for Amba Dongar, a parental phonolitic silicate melt for the complex cannot be ruled out.

\section{Conclusions}

Trace and rare earth element contents and their normalized patterns of Amba Dongar carbonatites are akin to those observed elsewhere. The incompatible trace element concentrations show a general increasing trend: alkaline silicate rock $<$ calcite carbonatite $<$ ferrocarbonatite. The contents and ratios of various trace elements clearly show that the calcite carbonatites and ferrocarbonatites of Amba Dongar have fractionally crystallized from a parental carbonate melt. We also find that the alkaline silicate rocks do not belong to the same crystallization sequence as the carbonatites, instead they represent products of fractional crystallization of a parental silicate melt. Our modeling efforts using the concentration data for the rocks of Amba Dongar and partitioning data of nine trace elements for a silicate-carbonate melt system yield results that are consistent with the suggestion that the parental carbonate and silicate melts for the complex have been derived from a mantle derived primary magma as a result of liquid immiscibility.

\section{Acknowledgements}

We thank N Sharma for his help during the fieldwork, and S K Pattanayak for preparing figure 1. We also thank Keith Bell, L G Gwalani, and $\mathrm{R}$ Ramesh for their constructive reviews.

\section{References}

Basu A R, Renne P R, Das Gupta D K, Teichman F and Poreda R J 1993 Early and late alkali igneous pulses and a high ${ }^{3} \mathrm{He}$ plume origin for the Deccan flood basalts; Science 261 902-906

Bell K 1989 Carbonatites: Genesis and Evolution (London: Unwin Hyman)

Bell K and Tilton G R 2002 Probing the mantle: the story from carbonatites; EOS Trans. 83 273-277

Bevington P R, Robinson D K and Bevington P 2002 Data Reduction and Error Analysis for the Physical Sciences, (New York: McGraw-Hill Science)

Dawson J B and Hinton R W 2003 Trace-element content and partitioning in calcite, dolomite and apatite in carbonatite, Phalaborwa, South Africa; Mineral. Mag. 67 921-930

Dawson J B, Smith J V and Steele I M 1994 Trace-element distribution between coexisting perovoskite, apatite and titanite from Oldoinyo Langai, Tanzania; Chem. Geol. $117285-290$

Dunworth E A and Bell K 2001 The Turiy Massif, Kola Peninsula, Russia: Isotopic and geochemical evidence for multi-source evolution; J. Petrol. 42 377-405

Gwalani L G, Rock N M S, Chang W-J, Fernandez S, Allègre C J and Prinzhofer A 1993 Alkaline rocks and carbonatites of Amba Dongar and adjacent areas, Deccan Igneous Province, Gujarat, India. 1. Geology, petrography and petrochemistry; Mineral. Petrol. $\mathbf{4 7}$ 219-253

Hamilton D L, Bedson P, Esson J 1989 The behaviour of trace elements in the evolution of carbonatites. In: Carbonatites: Genesis and Evolution, (ed) K Bell (London: Unwin Hyman) 405-427

Harmer R E and Gittins J 1998 The case for primary, mantle-derived carbonatite magma; J. Petrol. 39 18951903

Iwata N 1997 Geochronological study of the Deccan volcanism by ${ }^{40} \mathrm{Ar-}{ }^{39} \mathrm{Ar}$ method, Ph.D. thesis, Univ. Tokyo

Ionov D and Harmer R E 2002 Trace element distribution in calcite-dolomite carbonatites from Spitskop: inferences for differentiation of carbonatite magmas and the origin of carbonatites in mantle xenoliths; Earth Planet. Sci. Lett. 198 495-510

Jones J H, Walker D, Picket D A, Murrel M T and Beate $\mathrm{P} 1995$ Experimental investigations of the partitioning of $\mathrm{Nb}, \mathrm{Mo}, \mathrm{Ba}, \mathrm{Ce}, \mathrm{Pb}, \mathrm{Ra}$, Th, $\mathrm{Pa}$ and $\mathrm{U}$ between immiscible carbonate and silicate liquids; Geochim. Cosmochim. Acta 59 1307-1320

Keller J and Spettel B 1995 The trace element composition and petrogenesis of natrocarbonatites. In: Carbonatite Volcanism: Oldoinyo Lengai and the Petrogenesis of Natrocarbonatites (eds) K Bell and J Keller (Springer) $70-86$

Klemme S and Dalpé C 2003 Trace-element partitioning between apatite and carbonatite melt; Am. Mineral. $\mathbf{8 8}$ 639-646

Klemme S and Meyer H-P 2003 Trace element partitioning between baddeleyite and carbonatite melt at high pressures and high temperatures; Chem. Geol. 199 233-242

Korobeinikov A N, Mitrofanov F P, Gehör S, Laajoki K, Pavlov V P and Mamontov V P 1998 Geology and copper sulphide mineralization of the Salmagorskii Ring Igneous Complex, Kola Peninsula, NW Russia; J. Petrol. 39 2033-2041

Laul J C 1979 Neutron activation analysis of geologic materials; Atm. Energy Rev. 17 603-695 
LeBas M J 1989 Diversification of carbonatite. In: Carbonatites: Genesis and Evolution (ed) K Bell (London: Unwin Hyman) 428-445

Lee W J and Wyllie P J 1997 Liquid immiscibility in the join $\mathrm{NaAlSiO}_{4}-\mathrm{NaSi}_{3} \mathrm{O}_{8}-\mathrm{CaCO}_{3}$ at $1 \mathrm{Gpa}$ : Implications for crustal carbonatites; J. Petrol. 98 1113-1135

Petibon C M, Kjarsgaard B A and Jenner G A 1998 Phase relationships of a silicate-bearing natrocarbonatite from Oldoinyo Lengai at 20 and $100 \mathrm{MPa}$; J. Petrol. 39 $2137-2151$

Ray J S 1998 Trace element and isotope evolution during concurrent assimilation, fractional crystallization and liquid immiscibility of a carbonated silicate magma; Geochim. Cosmochim. Acta 62 3301-3306

Ray J S and Pande K 1999 Carbonatite alkaline magmatism associated with continental flood basalts at stratigraphic boundaries: cause for mass extinctions; Geophys. Res. Lett. 26 1917-1920

Ray J S, Pande K, Pattanayak S K 2003 Evolution of Amba Dongar carbonatite complex: Constraints from ${ }^{40} \mathrm{Ar}-{ }^{39} \mathrm{Ar}$ chronologies of the Inner Basalt and an alkaline plug; Int. Geo. Rev. 45 857-862

Ray J S, Pande K and Venkatesan T R 2000a Emplacement of Amba Dongar carbonatite-alkaline complex at Cretaceous/Tertiary boundary from ${ }^{40} \mathrm{Ar}-{ }^{39} \mathrm{Ar}$ chronology; Proc. Indian Acad. Sci. (Earth Planet. Sci.) 109 $39-47$

Ray J S and Ramesh R 1999 Evolution of carbonatite complexes of Deccan flood basalt province, India: Stable carbon and oxygen isotopic constraints; J. Geophys. Res. $10429471-29482$

Ray J S, Trivedi J R, Dayal A M 2000b Strontium isotope systematics of Amba Dongar and Sung Valley carbonatite-alkaline complexes, India: evidence for liquid immiscibility, crustal contamination and long-lived $\mathrm{Rb} / \mathrm{Sr}$ enriched mantle sources; J. Asian Earth Sci. 18 $585-594$

Simonetti A, Bell K and Viladkar S G 1995 Isotopic data from the Amba Dongar carbonatite complex west-central India: Evidence for an enriched mantle source; Chem. Geol. (Isot. Geosci.) 122 185-198
Srivastava R K 1997 Petrology, petrochemistry and genesis of rift-related carbonatites of Ambadungar, India; Miner. Petrol. 61 47-66

Sun S -s and McDonough W F 1989 Chemical and isotopic systematics of oceanic basalts: implications for mantle composition and processes; In: Magmatism in the Ocean Basins, (eds) A D Saunders and M J Norry Geol. Soc. Spl. Pub. 42 313-345

Sweeney R J 1994 Carbonatite melt compositions in the Earth's mantle; Earth Planet. Sci. Lett. 128 259-270

Veksler I V, Nielsen T F D and Sokolov S V 1998a Mineralogy of crystallized melt inclusions from Gardiner and Kovdor ultramafic alkaline complexes: Implications for carbonatite genesis; J. Petrol. 39 2015-2031

Veksler I V, Petibon C, Jenner G A, Dorfman AM and Dingwell D B 1998b Trace element partitioning in immiscible silicate-carbonate liquid systems: an initial experimental study using a centrifuge autoclave; J Petrol 39 2095-2104

Viladkar S G 1996 Geology of the carbonatite-alkalic diatreme of Amba Dongar, Gujarat. A monograph published by GMDC, Ahmedabad

Viladkar S G and Dulski P 1986 Rare earth element abundances in carbonatites, alkaline rocks and fenites of Ambadungar, Gujarat, India; N. Jb. Miner Mh. H1 $37-48$

Viladkar S G and Wimmenauer W 1992 Geochemical and petrological studies on the Amba Dongar carbonatites (Gujarat, India); Chem. Erde 52 277-291

Wendlandt R F and Harrison W J 1979 Rare earth element partitioning between immiscible carbonate and silicate liquids and $\mathrm{CO}_{2}$ vapor: Results and implications for the formation of light rare earth enriched rock; Contrib. Mineral. Petrol. 29 242-254

Williams-Jones A E and Palmer D A S 2002 The evolution of aqueous-carbonic fluids in the Amba Dongar carbonatites, India: implications for fenitization; Chem. Geol. $185283-301$

Woolley A R and Kemp D R C 1989 Carbonatites: nomenclature, average chemical compositions and element distribution; In: Carbonatites: Genesis and Evolution, (ed) K Bell (London: Unwin Hyman) 1-14 